\title{
Review
}

\section{Europe beyond universalism and particularism}

Susanna Lindberg, Mika Ojakangas and Sergei Prozorov (eds.), Palgrave Macmillan, Basingstoke, 2014, x+194 pp., ISBN: 978-1137361813

Contemporary Political Theory (2016) 15, e29-e31. doi:10.1057/cpt.2015.14; published online 26 May 2015

Born of a 3-year project titled 'Rethinking Cultural Diversity in Europe: Beyond Universalism and Particularism', and positioned as an 'interdisciplinary dialogue between continental philosophy, political theory and international relations', Europe Beyond Universalism and Particularism aims at nothing short of 'develop[ing] a new concept of universality' to inform a new European politics (p. 4-5). Although the universalities the contributors to this volume explore are not entirely new, the interminable crises of 'old' and 'new' Europe testify to the value and timeliness of considering them anew, and exploring the possibilities they open for both European politics and Europe as a political project.

Susanna Lindberg, Mika Ojakangas and Sergei Prozorov propose early on in the Introduction that universality ought to be approached 'not in terms of the unitary and the same' (p. 4) but as a 'space of coexistence of singularities, exposed to and touching each other without subsuming the other under the same' (p. 5). Drawing on Husserl and 'the Greeks' Timo Miettinen (see Chapter 3, 'The Particular Universal: Europe in Modern Philosophies of History') articulates such universality as a 'formal' rather than 'substantial' universalism - a universalism 'interested in those conditions on the basis of which different traditions allow themselves to be translated and mediated with each other' (p. 79). As opposed to substantial universalism - characterized by a particular content or substance formal universalism is a 'universal attitude', perhaps even ethos, grounded in 'a multiplicity of particulars' (p. 79).

Put differently still by Ojakangas (see Chapter 1, 'European Political Universalism: A Very Short History'), it is a 'universalism of grace'. On exploring three forms of political universalism in European historical-philosophical tradition (the universalism of moral standard, the universalism of human nature and the universalism of worth) Ojakangas proposes a fourth - the universalism of grace. Ojakangas offers the following by means of explanation:

In the body of Christ, a Jew is not the same as a Greek - everyone is different - but in exposing themselves to the process of becoming-nobody in the event of grace 
without law and identity they become the same - or rather, it is this becoming which is the same for all. (p. 28)

Thus, in a universalism of grace, what is universal or same is the process of becoming other than oneself. More precisely, what is universal is the process of 'becomingnobody' or, as Prozorov puts, following Giorgio Agamben (see Chapter 7, 'What Is the Other of Europe?'), becoming a 'non-positive and non-representable singularity ... whose essence is contained entirely in its existence and which evades any positive identification' (p. 155).

These interventions into the concept of universality are, of course, not entirely congruous. Yet taken together they foreground elements of a distinct and often neglected interpretation of universalism. This constitutes one of the core contributions of the volume. Having foregrounded this interpretation of universalism, the volume begins to consider the potential such interpretation offers for rethinking both European politics and Europe as an ethico-political project. Invoking his previous work, Europe, or the Infinite Task (2008), Gasché, for instance, imagines Europe not as an 'idea' but as an infinite task (see Chapter 2, 'Is "Europe" an Idea in the Kantian Sense?'). For Gasché, Europe is not 'a theoretical model to be practically realized ... [nor] a regulative idea ... which provides the guidelines and telos for a praxis aiming at its full realization' (p. 62). Europe is the proper name for an absolute and indefinite urgency of openness and responsibility toward the other (p. 62), and thus 'a singular token for an equally singular referent' (p. 61). Although, as Lindberg, Ojakangas and Prozorov suggest in the Introduction, rethinking the European project as a 'singular universal' falls well short of a practical policy design, it does open up some interesting political possibilities.

One such possibility is explored by Lindberg (see Chapter 5, 'Unhomely Europe'), who considers what reconstituting Europe as a 'temporary community of residents' might offer (p. 117). Lindberg's depiction of Europe as a community of residents evokes Agamben's community of singularities (or whatever-beings) and Friedrich Nietzsche's Europe of refugees. Yet the concept of 'residency', together with Lindberg's evocation of Martin Heidegger's work on dwelling, rootedness and homeliness, gives the imagined European community of residents a less ethereal, and a more corporeal, mundane (or everyday) existence. For Lindberg, Europe is always already 'uprooted' and 'unhomely' - geographically, linguistically and politically. As a temporary community of residents - as opposed to a 'permanent community of natives' (p. 117) based on 'old ideas of nationality or citizenship' (p. 103) - Europe can transform from a community of 'destiny and birth' to a community of 'choice and hospitality' (p. 103). In a slightly puzzling sentiment, Lindberg suggests that Europe should be reinvented as a community of residents 'not because it is better, but because it is more honest' (p. 103). Although it may indeed be more honest, wouldn't it also be infinitely 'better'?

When imagining the European community of residents as grounded in the experience of migration, homelessness and uprootedness, Lindberg carefully 
acknowledges that an affirmation of homelessness and uprootedness must contend with the fact that 'forced homelessness is generally a devastating human catastrophe' (p. 110), and, one could add, a catastrophe in which Europe had, and continues to have, a hand. Like other contributors to the volume, Lindberg also gestures toward de-centering Europe - countering what could be perceived as an implicit or underlying motif of European exceptionalism with a warning that the phenomenon of homelessness is 'neither new nor specifically European' (p. 106). Yet despite such warnings, vestiges of exceptionalism seem to haunt both Lindberg's chapter - when she discusses, for instance, the 'unique' linguistic diversity of Europe (p. 114) - and other contributions. This is perhaps inevitable, for as Nietzsche suggests, attempts to reinterpret a set of practices or way of life can never utterly eradicate previously accumulated meanings and interpretations (Geuss, 1994, p. 331). Yet it remains disconcerting, and should perhaps occasion us to once again consider, whether, on balance, Europe is indeed the most appropriate name for the kind of politics we want to imagine.

\section{References}

Gasché, R. (2008) Europe, or The Infinite Task: A Study of a Philosophical Concept. Stanford, CA: Stanford University Press.

Geuss, R. (1994 [2001]) Nietzsche and genealogy. In: J. Richardson and B. Leiter (eds.) Nietzsche. New York: Oxford University Press, pp. 322-340.

Agnes Czajka

Open University, Walton Hall, Milton Keynes, MK7 6AA, UK 